\title{
Ekonomik ve Mali Boyutlarıyla Robot Vergisi
}

\section{Robot Tax with its Economic and Financial Dimensions}

\section{Dr. Öğr. Üyesi Deniz TURAN ${ }^{1}$}

Başvuru Tarihi: 31.12.2019

Kabul Tarihi: 07.03.2020

Makale Türü: Araştırma Makalesi

\section{Öz}

21. yüzyılda robot teknolojisinde yaşanan hizh gelişmeler, toplumu ve ekonomiyi temelden dönüştürmeye başlamıştır. Günümüzde üretimden hizmet sektörüne kadar her alanda yaygın şekilde kullanılan ve ekonomik verimliliği artırması yanında teknolojik işsizliğe de yol açan akıllı robotların vergilendirilmesi konusu ekonomik ve sosyal boyutları ile ele alınmaya başlanmıştır. Yapılan çalışma, robotların işgücü piyasası, gelir dağılımı ve kamu mali dengesi üzerine etkilerinin incelenerek bir robot vergisinin gerekliliğinin ekonomik gerekçeleri açıklığa kavuşturmayı amaçlamaktadır. Bu çalışmanın bulguları şunlardır; Robot teknolojisi işgücü piyasasında yeni bir küresel dengenin oluşmasına yol açacaktır. Toplumda gelirin küçük bir sermayedar kesimde toplanmasina engel olmak ve otomasyon devriminden olumsuz etkilenenlere potansiyel olarak yardımcı olmak amacıyla robotların elektronik kişi sıfatıyla yasal bir kişilik tanımlanması ve robot vergisi alınmasi gerekmektedir.

Anahtar Kelimeler: Endüstri Devrimleri, Teknolojik İşsizlik, Robot Vergisi, Ayırma İlkesi

\begin{abstract}
Rapid developments in robot technology in the 21st century started to transform society and economy fundamentally. Today, the issue of taxation of smart robots, which is widely used in every field from production to the service sector and leads to increasing economic efficiency as well as technological unemployment, has begun to be addressed with its economic and social dimensions. This study aims to clarify the economic reasons for the necessity of a robot tax by examining the effects of robots on the labor market, income distribution and public financial balance. The findings of this study are as follows; Robot technology will lead to a new global balance in the labor market. In order to prevent the collection of income in a small capitalist society and to potentially help those who are negatively affected by the automation revolution, robots must be defined as an electronic person and a robot tax is required.
\end{abstract}

Keywords: Industrial Revolutions, Technological Unemployment, Robot Tax, Separation Principle

\footnotetext{
1 Polis Akademisi Başkanlığı, Güvenlik Bilimleri Enstitüsü, ahmetdenizturan@gmail.com, ORCID:0000-0002-6697-2721
} 


\section{Giriş}

Robotlar günümüzde sadece sanayide değil hayatın her alanında kullanılmaktadır. Robot ve yapay zekada teknolojisi alanında yaşanan hızlı ilerlemenin hayatlarımızı nasıl dönüştüreceği konusu, teknolojik boyutlarının yanı sıra makroekonomi ve kamu düzenine etkilerine kadar geniş bir yelpazede tartışılmaktadır. Metal yakalı çalışan olarak da adlandırılan robotlar, günümüzün modern köleleri olmaya adaydır. Robotların insanlığı angaryadan kurtarması ve ortaya çıkacak gelir fazlasının adil dağıtılması halinde toplumları refaha kavuşturması beklenmektedir.

Literatürde bulunan diğer çalışmalardan farklı olarak bu çalışmada robotların tanımı, ekonomik ve sosyal etkileri ile robot vergisi uygulamasının ortaya çıkaracağı sorunların tartışılması ile yetinmemiş, aynı zamanda robotların kamu mali dengesi üzerine etkileri harcama ve vergi boyutları ile analiz edilerek, robot vergisinin uygulanabilmesi için yol gösterici önerilerde bulunulmuştur.

Çalışmanın amacı, robotların işgücü piyasası, gelir dağılımı ve kamu mali dengesi üzerine etkilerinin incelenerek bir robot vergisinin ekonomik ve sosyal gerekliliğini, verginin uygulanabilmesi için alınması gereken tedbirleri ve robot vergisi uygulamasının olası etkilerini açığa kavuşturmaktır.

Çalışmada ilk olarak, endüstri devrimleri ve robot teknolojisinde yaşanan gelişmeler ile birlikte işgücü piyasasında ortaya çıkan teknolojik işsizlik sorunu ele alınmaktadır. Takip eden kısımda ekonomide robot kullanımının gelir dağılımı ile kamu mali dengesi üzerine olası etkileri irdelenmiştir. Son kısımda ise robotların vergilendirilmesine yönelik alınacak yasal ve ekonomik önlemler ile robot vergisinin etkinliği hakkında açıklamalarda bulunulmuştur.

\section{Endüstri Devrimleri ve Robot Teknolojisi}

18. yüzyıldan günümüze kadar beş endüstri devrimi yaşamış ve günümüzde insansız robot teknolojilerin kullanımı aşamasına ulaşılmıştır. Mekanizasyon olarak da ifade edilen ilk sanayi devrimi (Endüstri 1.0), 18. yüzyılda su, rüzgâr ve buhar gücü gibi çevre gücünün makinelerde kullanılarak mekanik üretim sistemlerinin ortaya çıkmasına olanak vermiştir. Buhar gücü ile çalışan lokomotifler bu dönemin en önemli örneğini temsil etmektedir. İkinci sanayi devriminde (Endüstri 2.0), 19. yüzyılda elektriğin keşfi ile birlikte üretimde elektrik gücü kullanılmaya başlanmış ve montaj hatlarında seri üretime geçilmiştir. Üçüncü sanayi devriminde (Endüstri 3.0) ise dijital sistemler, elektronik altyapılar ve bilgi teknolojileri üretimde kullanılmaya başlandı. Üretim süreçlerinde otomasyona geçildi ve yazılım destekli üretim ön plana çıktı. 21.yüzyılda gerçekleşen dördüncü sanayi devriminde (Endüstri 4.0), endüstriyel faaliyetler ile bilişim teknolojileri bir araya gelerek nesnelerin ve hizmetlerin interneti ile siber-fiziksel sistemler üretim ortamına sokulmuştur. Dördüncü sanayi devriminin en önemli parçasını oluşturan robotik sistemler ve yapay zekâ, üretimde ve hizmet sektöründe insan gücünün önemini yitirmesine yol açmıştır (Geniş Bilgi için Bkz: Marcovitz, 2013; Allen, 2017; Johannessen, 2019; Popkova, Ragulina ve Bogoviz, 2019). 
Ocak 2016 tarihinde Japon hükümeti tarafından ilk kez ortaya konan ve Toplum 5.0 olarakta adlandırılan Endüstri 5.0, Endüstri 4.0 ile geliştirilen teknolojik yeniliklerin topluma entegre edilmesi temeline dayanmaktadır ve toplum odaklı insansız teknolojilere geçilmesi hedeflenmektedir (Okan Gökten, 2018, s. 884). Siber alan ile gerçek toplumun entegre olduğu bu aşamada, bir fabrikada az sayıda yönetici insan grubu tarafindan verilen görevler robotlar tarafından yerine getirilmektedir.

Üçüncü sanayi devrimi ile birlikte üretim süreçlerinde kullanılmaya başlayan yazılım teknolojisi, dördüncü sanayi devrimi ile birlikte yapay zekânın üretimde kullanılması ile ileri bir aşamaya geçmiştir. Günümüzde yapay zekânın ve diğer ileri bilgisayar teknolojileri dahil olmak üzere otomasyon teknolojilerindeki hızlı gelişmeler ekonomimizi, toplumu ve dünyayı temelden dönüştürmeye başlamıştır. Robotlar günümüzde hayatımızın, işimizin ve eğlencemizin her alanında kullanılmaktadır. Gelecek robot çağı, sosyal, ekonomik ve yasal düzen açısından birçok soruyu gündeme getirmektedir. Robotlar ve yapay zekâ (AI) devriminin hayatlarımızı nasıl dönüştüreceği konusu, teknolojik boyutlarının yanı sıra makroekonomi ve kamu politikasına etkilerine kadar geniş bir yelpazede tartışılmaktadır.

$\mathrm{Bu}$ çalışmanın konusunu oluşturan robot vergisinin ortaya çıkardığı en önemli ve açıklanması gereken husus terimler ve tanımlarda yatmaktadır. Robot kelimesinin kökenleri Çekçe'de zorunlu çalışma anlamına gelen "robota" ve hizmet anlamına gelen "robotrick" kelimelerinde yatmaktadır (Bootle, 2019, s.4). Artuklular zamanında yaşamış bilim adamı El Cezeri, sibernetik ve robot teknolojinin öncüsü olarak bilinir ancak robot kelimesi ilk kez Çek bilim kurgu yazarı Karel Çapek, 1920 yılında yazdığı ve isyan ederek fabrikayı ele geçiren robotların ele alındığ "Rossums Universal Robots" adlı bilimkurgu tiyatro eserinde kullanılmıştır.

Üretimden hizmet sektörüne kadar her alanda yaygın şekilde kullanılan robotlar insan hayatını kolaylaştırmaktadır. Her ne kadar üniform bir "robot" tanımı mevcut olmasa da genel olarak robotlar, şekli ve görünümü ne olursa olsun, belirli şekillerde hareket etmek için programlanabilen mekanik cihazlar olarak tanımlanır (Bootle, 2019, s.4). Diğer bir ifade ile robot, insan emrinde otomatik olarak bir görevi veya işlevi yerine getirebilen akıllı özerk makinelerdir (Marwala, 2018, s.2). Makinelerin aksine; otonom yapıları, öğrenme, ilerleme ve karar verebilme yetenekleri, robotların "akıllı" olarak nitelendirilmelerine yol açmıştır. Mevcut ve geçmiş teknoloji arasındaki temel fark, eski otomatik makinelerin yerini akıllı özerk makinelerin, diğer bir ifade ile akıllı robotların almasıdır (Bottone, 2018, s.3). Bu kapsamda bilgisayarlar, yazılım programları, ATM’ler, insansız hava araçları gibi yazılımsal ürünler ve fiziki unsurlar robot tanımı içerisinde yer almaktadır. Bu tanımlarda yeterli özerklik ve öğrenme, ilerleme ve karar verme kapasitesi ile çalışabilme yeteneğini kilit bir özellik olarak öne çıkmaktadır (Mazur, 2019, s.279). 
Avrupa Birliği Hukuk İşleri Komitesi raportörü Mady Delvaux, robotlara vergi konulması konusu hususunda hazırladığı tavsiye raporunda, akıllı özerk robotları şu özelliklere sahip yapılar olarak tanımlanmıştır (Delvaux, 27.01.2017, s.8);

- sensörler aracılığıyla ve/veya çevresinden veri değişimiyle bir işi yapma ve veri analiz etme,

- deneyim ve etkileşim yoluyla kendi kendine öğrenme (isteğe bağl1 kriter),

- en azından küçük bir fiziksel destek,

- davranış ve eylemlerinin çevreye adaptasyonu,

- biyolojik anlamda yaşamın olmaması.

Burada yapay zekayı içeren akıllı robotları dar ve geniş kapsamda sınıflandırmak mümkündür (Turner, 2019, s.6). Dar kapsamda akıllı robotlar, belirli bir amaç veya hedefe ulaşmak için sınırlı hedefler doğrultusunda sadece tasarlanan görevleri yerine getiren teknikleri kullanırlar. Bugün dünyadaki akıllı robotların büyük çoğunluğu bu dar ve sınırlı tipe daha yakındır. Geniş kapsamda ise sınırsız bir dizi hedefe ulaşma ve hatta belirsizlik veya belirsizlikler de dahil olmak üzere bağımsız olarak yeni hedefler belirleme yeteneğine sahip robotlardır. Frankenstein, Star Wars, Terminatör, 2001: A Space Odyssey vb. filmlerde cansız maddelerden üretilen ve insan yetenekleri seviyesine yaklaşan akıllı robotlar tasvir edilmesine karşılık, Kur'an-1 Kerim'de Hicr Suresi 26. Ayet'de “Andolsun biz insanı şekillenebilir özlü balçıtan, (şekil verilip) kurutulmuş çamurdan yarattık" ifadesinde açıklandığ üzere, cansız bir maddeden yaratılan ve zekâ verilen insanın fiziki ve zihinsel yeteneklerine sahip akıllı bir robot henüz yapılamamıştır.

Robotik sistemlerin insan hayatının her alanına nüfuz etmeye başlaması ve günlük yaşamımızın ayrılmaz bir parçası halini alması, robot etiği konusunda artan kaygıların öne çıkmasına yol açmıştır. Isaac Asimov, robotların zarar verme ve görme potansiyelini ve dolayısıyla kullanımlarını ve gelişmelerini yöneten etik (ve belki de yasal) bir çerçeveye duyulan ihtiyacı fark etmiştir. 1942'de yazdığı ve 1950 yılında dokuz bilimkurgu öyküsünün toplandığ 1 "Ben Robot" kitabında yer verdiği Kovalamaca "Runaround" adlı çalışmada üç temel robot yasasına değinmiştir (Asimov, 2013, s.31).

- Bir robot, insanlara zarar veremez ya da eylemsiz kalarak onlara zarar gelmesine göz yumamaz.

- Bir robot, bu emirlerin birinci kanunla çeliştiği durumlar dışında, insanlar tarafından verilen emirlere uymak zorundadır.

- Bir robot, birinci veya ikinci kanunlarla çelişmediği sürece kendi varlığını korumalıdır.

Asimov daha sonra adını "sıfırcı yasa" olarak koyduğu dördüncü robot yasasını eklemiştir. Buna göre "Hiç bir robot, insanlığa zarar veremez ya da hareketsiz kalarak insanliğın zarar görmesine izin veremez". Bu yasa ile insanlığa zarar verecek bir kişinin gerektiğinde robotlar tarafından engellenmesi gerektiğine vurgu yapmaktadır. 
Robotların toplumda yol açtığı dönüşümün olumlu ya da olumsuz yönleri bulunmaktadır. Robot devriminin hepimizi zenginleştireceği ve insanlı̆̆1 angaryadan kurtaracağı savunanlara göre robotlar, zor ve hatta tehlikeli faaliyetleri (bomba imha, kirli alanların temizlenmesi vb.) gerçekleştirebilir ve verimliliği arttırırlar. Böylece serveti artan ve daha yüksek yaşam standardı kazanan bireyler daha farklı ve yaratıcı faaliyetlere odaklanabilir. Gerçekten de üretimden hizmet sektörüne birçok alanda kullanımının insanlığa olan katkıları yadsınamaz. Robot teknolojisinin gelişimi, yeni iş kollarının ortaya çıkmasına ve nitelikli işgücü istihdamının artmasına yol açmıştır.

Bu yeni teknolojilerin hızlı bir şekilde ortaya çıkması topluma sayısız faydalar sağlasa da aynı zamanda önemli zorluklar da sunmaktadır. Robotların ekonomide yaygın teknolojik işsizlik, ekonomik adaletsizlik ve düşük vergi gelirlerine neden olacağı endişeleri günümüzde tartışılmaktadır. Robotların emek sektöründe özellikle rutin çalışanlar ile mavi yakalı çalışanların yerini almaya başlaması, beraberinde kişilerin kariyer ortasında yeni mesleklere geçmelerine de yol açmaktadır. Diğer taraftan robotlar, ekonomik dengeyi bozucu ve özellikle devletlerin vergi gelirlerinin azaltııı etkiler ortaya çıkarmaktadır.

\section{Robotlar, İşgücü Piyasası ve Teknolojik İşsizlik}

Amerikalı yazar Kurt Vonnegut, General Electric'te gördüğü delikli kart makinesi deneyimi üzerine 1952'de yazdığı “Otomatik Piyano” adlı romanında (Vonnegut, 1952) teknolojik işsizlik konusunu ele almıștı. Romanda, gelecekte robotların insan emeğini tasfiye ettiği ve her türlü işin otomasyonla yapıldığı bir düzenden bahseder. Günümüzde robot teknolojisinde yaşanan devasa dönüşüm, insanlığı Vonnegut'in tasvir ettiği distopya dünyasına yaklaştırmaya başladığı yönünde önemli ipuçları vermektedir.

Metal yakalılar olarak da ifade edebileceğimiz robotlar, günümüzde sadece sanayide değil hayatın her alanında kullanılmaya başlanmıştır. Robotların üretimde ve hizmet sektöründe kullanımının artmasının işsizliği artıracağı hususu günümüzde tartışma konusudur. Bir yandan uzmanlar bu korkunun abartıldığını ve teknolojik işsizliğin geçici bir uyumsuzluk aşaması olacağını savunmaktadırlar. Buna göre robot kullanımı verimliliği artıracak, dolayısıyla ekonomik büyümeyi teşvik edecek ve daha fazla emek talebi ortaya çıkaracaktır. Mevcut işlerin genişlemesini teşvik etmenin yanı sıra yeni iş fırsatları yaratacaktır (Mazur, 2019, s.284).

Antik Yunan'da aşırı çalışmanın kişinin kendisini köleleştirmesine yol açtığına vurgu yapılmaktadır. İnsanları düşünmeye sevk eden, özelliklede felsefe ile değerlendirilen boş zaman ise medeni bir hayatın ilk koşulu sayılmaktadır. Aristoteles'e göre boş zamanı ortaya çıkaran şey ise kölelerdir (Cevizci, 2001, s. 222-224). Günümüzde insan kölelerin yerini robotlar almaya başlamıştır. Bu kapsamda insanlar yeni teknolojileri tasarlama ve geliştirmede hayati bir rol üstlenmeye devam edecektir ve karşılığında robotların birçok insanın eğitim, kültür ve sanat için daha fazla vakit ayırmasına yol açması umut edilmektedir.

Sanayi devrimi sonrasında otomasyonun geçim kaynaklarını tehdit ettiğine inanan ve sanayide makinelerin kullanılmasına karşı çıkan İngiliz tekstil işçileri, Ludizm Hareketini başlatmışlardı. 
İngiliz fabrika yasalarını eleştiren Karl Marx, makineleşmenin ahlakın, doğanın, yaş ve cinsiyetin, gece ve gündüzün bütün sınırlarını yıktığını, çalışanları düşük ücretli işlere zorlayacağını savunmaktaydı (Marx, 2011, 270-289). Yirminci yüzyıl boyunca otomasyon kaygıları devam etti ve ikinci ve üçüncü sanayi devrimi ile birlikte ofis bilgisayarlarının ve fabrika robotlarının yaygın şekilde kullanılmasıyla tekrar canlandı. 1960 seçim kampanyasında John F. Kennedy, otomasyonun emek için yeni bir refah ve bolluk umudu sunduğunu ancak endüstriyel yer değiștirmenin karanlık tehdidinin işsizliği artırdığını ve yoksulluğu derinleştirdiğini, otomasyonun erkeklerin yerini aldığı bir zamanda tam istihdamı sürdürmenin altmışlı yılların en büyük iç meydan okuması olarak gördüğünü ifade etmiştir (Abbott ve Bogenschneider, 2018, s.157-158).

Teknolojik yeniliğin hızı son yıllarda doğrusaldan parabolik hale gelmiştir. Özellikle Endüstri 4.0 devrimi, önceki endüstri devrimlerden farklılıklar içermektedir. Teknolojik gelişmelerin birçok farklı alandaki birleşik etkisinin toplumları derinden dönüştürdüğü bir döneme girilmiştir. Robotların insanları ikame edeceği ve teknolojik işsizliğe neden olacağı görüşü “yerinden etme etkisi” olarak adlandırılmaktadır (Ela, 2019, s.887-888). Özellikle akıllı robot teknolojisi, düşük vasıflı işçilerin (temizlikçi, şoför, kasiyer) yanı sıra beyaz yakalı işçilerin ve çeşitli alanlardaki profesyonellerin (doktor, avukat yardımcılığı, büyük veri analizi, suçlu tespiti, besteci, denetçi vb.) yerini alabilmektedir. McKinsey \& Company'nin "Gelecekte İstihdam, Yetenekler ve Gelirler Nasıl Şekillenecek?" başlıklı raporunda; otomasyon, yapay zekâ ve dijital teknolojilerle yaşanan gelişmelerin sonucunda 2030 yılına kadar dünyada yaklaşık 400 milyon ila 800 milyon insan işini kaybedebileceği, 75 milyon ila 375 milyon arasında insanın ise kariyer ortası geçiş yaparak yeni beceriler kazanmaları gerektiği ve başka alanlarda çalışmak zorunda kalacakları iddia edilmektedir (Manyika ve diğ., 2017, s.11).

İnsanların günümüzde üstlendiği ağır ve tehlikeli işlerin robotlar tarafindan gerçekleştirilmesinin insanlığın refahını artıracağı aşikardır. Ancak hizmet sektöründe insanların yerini robotların alması, insanlar arasında iletişimin azalmasına ve yabancılaşmaya yol açma riski bulunmaktadır. Ayrıca Birinci Sanayi Devrimi ile başlayan makineleşme süreci göstermiştir ki teknolojik gelişmelere rağmen kapitalist üretim süreci günümüzde de Çin, Endonezya, Hindistan'da olduğu gibi en ucuz işgücünü kullanmaya devam etmektedir. Robot teknolojisi alanındaki gelişmeler bazı mesleklerin ortadan kalkmasına ve yeni üretim şekillerinin ortaya çıkmasına yol açarak işgücü piyasasında yeni bir küresel dengenin oluşmasına yol açacaktır.

Burada ki temel sorunsal robot teknolojisinde yaşanan gelişmelerin insan refahını nasıl etkileyeceğidir. Fizikçi Stephen Hawking bu konuda şu uyarıyı yapmaktadır; "makinelerin ürettiği servet paylaşılırsa herkes lüks bir boş zamanın tadını çıkarabilir ya da makine üreticileri servetin yeniden dağıtımına karşı başarılı bir şekilde lobicilik yaparsa çoğu insan mutsuz bir şekilde fakirleşebilir" (Rathi ve Hawking, 09.10.2015). Şimdiye kadar eğilim gittikçe artan eşitsizliğe neden olan teknoloji ile ikinci seçeneğe doğru gitmektedir. Bu nedenle robot teknolojisinin ortaya çıkardığı ekonomik eşitsizliklerin ayrıca ele alınması önem taşımaktadır. 


\section{Robotlar ve Gelir Dağılımı}

Bir toplumun refahını belirleyen en önemli etkenlerden biri olan adil gelir dağılımı, tam kamusal niteliğe sahiptir. Serbest piyasa koşullarını geliri ve serveti fazla olanların lehine işlemekte ve müdahale edilmediği taktirde adil olmayan bir gelir dağılımı ortaya çıkmaktadır (Çomaklı ve Turan, 2016, s.54-56). Robotların üretimden hizmet sektörüne hayatın her alanında kullanımı, beraberinde toplumda güçsüz kesimlerin Rawls'çı yaklaşımla korunmasını beraberinde getirmektedir. Robotların üretimde kullanımının gelir ve servet eşitsizliğini artıracağı yönündeki kaygıların temelini şu faktörler oluşturmaktadır;

- Vergi sisteminde bir değişiklik yapılmadan otomasyon maliyetlerinde yaşanacak azalmaların gelir eşitsizliğinde büyük bir artışa yol açma ihtimali bulunmaktadır (Guerreiroy, Rebeloz ve Teles, 2018, s.40-41). Çünkü robotlar rutin işleri ve düşük vasıflı işleri ortadan kaldırmasalar bile daha az maliyetli olan robotlarla rekabet edebilmek için, bu meslek mensuplarının ücretlerinde bir düşüş yaşanması ve bu pozisyonlardaki çalışanların işlerini sürdürmek için daha düşük ücretler kabul etmesi muhtemeldir. Bu adaletsizliği düzeltmek için yüksek gelirli bireylerin ödediği marjinal vergi oranları yükseltilmesi ve robotların vergilendirilmesi gerekmektedir.

- Robotların üretimde kullanımının artması, sermaye sahipleri genellikle varlıklı kişiler olduğu için, robotların sahiplerinin kazançlarının çalışanlara göre çok fazla artmasına, diğer bir ifade ile gelirin işçilerden sermaye sahiplerine transferinin hızlanmasına yol açacaktır. Bu durum toplumda gelirin küçük bir sermayedar kesimde toplanmasına yol açacaktır (Dunlop, 2017).

- Otomasyon sonucunda düşük vasıflı mesleklerde çalışanların ücretlerinde azalma yönünde bir baskı yaşanmasına karşılık, yüksek vasıflı meslek çalışanlarının ücretlerinde artış yaşanması durumunda, ücret farklarının giderek açılması ve gelir dağılımının bozulması sözkonusu olacaktır (Mazur, 2019, s. 287).

- Robot kullanımının ortaya çıkaracağı verimlilik ve büyümeye karşılık vasıflı çalışanların maaşlarının verimlilik artışı ile orantılı artmaması muhtemeldir. Mazur'un (2019, s. 289) belirttiği üzere Amerika'da, üretimde robotlara sahip olan kişilerin, ortaya çıan verimlilik artışının ekonomik faydalarından daha fazla yararlandığı görülmüştür.

Teknolojik olarak işsiz kalanların yeni iş türlerine geçişte yeniden eğitilmesi ve tamamlayıcı mesleklerde başarılı olmaları sağlanarak teknolojik işsizlikten kaynaklı risklerin azaltılması yoluna gidilebilir. Kamu fonlarını kullanarak bir istihdam biçiminden diğerine geçiş kolaylaştırılmalıdır. Diğer geçici bir çözüm yolu ise teknolojik işsizlere devletin maaşa bağlamasıdır. Ancak bir sonraki başlıkta ele alınacağı üzere burada dikkat edilmesi gereken husus, robot teknolojisinin vergi gelirlerini azaltıcı etkilerinin artması durumunda, devletlerin ekonomide ikinci en iyiye ulaşmak için gelir dağılımını düzeltici harcama politikalarını uygulama şansları zora girmektedir.

\section{Robotlar ve Kamu Mali Dengesi}

Otomasyonun sonucunda insan çalışanların yerini robotların alması, gelirin işgücünden sermaye gelirine doğru kaymasına ve sonuçta kamu harcamaları, ekonomik konjonktür ve 
vergileme boyutlarıyla kamu mali dengesini etkilemesine yol açmaktadır. İşçilerin robotlarla ikame edilmesi akabinde hükümet harcamalarının artması muhtemeldir. Çünkü işsizleri desteklemek ve yeni iş kolları için eğitmek amacıyla ek sosyal yardım programları gerekecektir. Diğer taraftan muhtemel bir vergi geliri kaybı, uzun vadeli mali ödeme güçlüğü ortaya çıkaracaktır (Mazur, 2019, s.292).

Robotların artan şekilde üretimde kullanımı sonucunda sermaye sahiplerinin gelirlerinin aşırı artışı, marjinal tüketim meyili işçilere göre daha düşük olanların elinde harcama gücünün yoğunlaşmasına ve sonuçta toplam talebin azalmasına yol açma riski bulunmaktadır. Diğer taraftan insanların teknolojik işsizlikle karşı karşıya kalmaları, robotların üreteceği malların kim alacağı sorusunu ortaya çıkarmaktadır. İstihdam olmazsa, müşterilerin bu ürünleri almak için parayı nereden bulacakları sorusu gündeme gelmektedir. Gittikçe daha fazla insan işsiz kaldıkça ekonomik daralma hemen hemen kaçınılmazdır (Chace, 2016, s.208-209).

Robotların yol açtığı işsizlikle yüzleşmek için otomasyon devriminden olumsuz etkilenenlere potansiyel olarak yardımcı olabilecek transfer harcamalarının yapılması gerekmektedir. Kısa vadeli çözüm olarak hükümetlerin işgücü piyasasından dişlananlar için hastalık sigortası ve işsizlik yardımları gibi sosyal yardım programlarını yürürlüğe koymaları gerekecektir (Bootle, 2019, s. 190-191). Ayrıca negatif gelir vergisi uygulamalarına gidilerek asgari geçim düzeyinin altında kalanlardan vergi alınmayabilir ve ekonomik destek verilebilir. Uzun vadede ise büyüyen bir teknolojik karmaşıklık içinde, özellikle düşük vasıflı işçileri kalıcı olarak yeniden kazanmak için eğitim sisteminde köklü bir reform yapmak ve kariyer ortası meslek geçişlerine uygun yeniden eğitim imkanlarının sağlanması gerekmektedir. Sonuçta hükümetler artan harcama talepleriyle karşı karşıya kalacaktır.

İşgücünün otomasyonunun hızlanması ve işgücü gelirinden sermaye gelirine doğru artan kayış, kamu harcamaları yanı sıra vergi gelirlerini de etkilemektedir. Vergi, devleti idare etmek, memurlara ödeme yapmak, devlet okullarını ve hastaneleri, yolları korumak ve sosyal hibeleri ödemek için çalıştırmak için kullanılır. Ancak mevcut vergi sistemleri, robot işçilere göre değil esas olarak insan işçilerin vergi vermesi üzerine tasarlanmıştır.

İşüucü bordro gelirlerinin vergilendirilmesi, işgücünden yapılan parafiskal kesintiler (sosyal güvenlik kesintileri vb.) ve işçilerin harcamalarının dolaylı olarak vergilendirilmesinden elde edilen vergi geliri, devletin vergi gelirlerinin en önemli gelir kalemlerini oluşturmaktadır. Çalışanların akıllı makineler ile yer değiştirmesi durumunda, eğer verimlilik artışı ve sonuçta ekonomik büyüme ortaya çıkarsa, kurumlar vergisi tahsilatı artacaktır. Ancak verimlilik artışı ve ekonomik büyümeden kaynaklı sermaye kazancı ve ticari kârın daha düşük vergi yüküne maruz kalmasına yol açacak durumlar söz konusudur. Şöyle ki; makineler için sermaye harcamalarında hızlandırılmış amortisman uygulamalarının yanısıra katma değer vergisi istisnaları gibi dolaylı vergilendirmede sağlanan çok sayıda cömert vergi teşviklerinin varlığı, kurumlar vergisi gelirleri artışını sınırlı düzeyde tutacaktır (Abbott ve Bogenschneider, 2018, s.156). Ayrıca, küreselleşen dünyada yaşanan vergi rekabeti sonucunda kurumlar vergisi 
oranlarının düştüğü göz önüne alındığında, kurumlar vergisi tahsilatı beklenen düzeyin altında kalacaktır.

Gerçek kişiler yerine işyerlerinde robot teknolojisini kullanmaya başlayan firmalar, gerçek kişiler için ödedikleri işveren kesintilerinden kurtulmakta ve vergiden kaçınmaktadırlar. Diğer bir sorun, robot teknolojisi kullanarak kazançları artan büyük sermaye sahiplerinin vergi cennetlerine kazançlarını kaydırarak vergi kaçırma olanakları bulunmasıdır. Ancak ücretlerinden stopaj yoluyla gelir vergileri tahsil edilen işçilerin gelir vergisini kaçırma imkânı bulunmamaktadır. Sonuçta çalışanların akıllı makineler ile yer değiștirmesi sonucunda ortaya çıkması düşünülen kurumlar vergisi gelirlerinde ki artış ile sermaye sahiplerinden elde edilmesi planlanan vergi gelirleri artışları, mevcut vergi mevzuatında bir düzenlemeye gidilmez ise yeterli düzeyde gerçekleşmeyecektir.

Kurumlar vergisi gelirlerinde ki muhtemel artışa karşılık, işsiz kalan kişiler kısa sürede başka bir yerde istihdam edilmezler ise gerçek kişilerin vergilendirilmesinden elde edilecek vergi gelirleri azalacak ve devletler önemli miktarda net gelir vergisi kaybı ile karşı karşıya kalacaklardır. Buradaki gelir vergisi kaybı, tahmini olarak otomasyondan kaynaklanan maaş azalışının efektif bir vergi oranıyla çarpılması sonucunda bulunabilir. Diğer tarafta robotlar gerçek kişiler gibi harcamada bulunmadıkları için devletin dolaylı vergi gelirleri de azalacaktır. Örnek verilecek olunursa, Ocak 2017 tarihli McKinsey Global Institute’nün hazırladığ 1 raporda, mevcut çalışma faaliyetlerinin yaklaşık yarısının mevcut teknolojiler kullanılarak otomatikleştirilebileceğini ve bunun sadece ABD'de yıllık ücretlerde 2,7 trilyon doları ortadan kaldıracağını iddia edilmektedir (Bottone, 2018, s.13).

Sonuç olarak mevcut vergi sistemleri uygulandığında robotların insanlar kadar iyi bir vergi mükellefi olmadığı görülmektedir. İnsan emeği robotlar ile değiştirildiği ve onlara benzer vergi rejimi uygulanmadığı sürece vergi tabanının daralacağı ve devletlerin, teknolojik işsizlikten kaynaklanan artan harcama talepleriyle karşılaştıkları bir dönemde önemli bütçe baskıları ile karşı karşıya kalacakları görülmektedir. Bu nedenle otomasyonun vergi gelirini azaltmasına izin verilmemeli ve vergi sistemi en azından robot ve insan işçiler arasında tarafsız olmalıdır. Kamu gelirindeki herhangi bir düşüş, başka bir yerden artan vergi gelirleriyle telafi edilmelidir. Robotların artan oranda emeğin yerine konmaları sonucunda politika yapıcıların büyük bir teknolojik işsizlik ve kamu kaynaklarının yetersizliği ile karşı karşıya kalması durumunda, robotlardan vergi alınması zorunlu olacaktır ve robot vergisi geleceğin en tartışmalı konusu olmaya adaydir.

\section{Robot Vergisi Önerileri ve Uygulanabilirliği}

İnsanlık tarihinde vergi konuları, parayı takip etme kuralı üzerine seçilmişlerdir. Halk pazarları, ticaretin gelişmesi sonucunda gümrükler, tarım ve hayvancılık, ücretler, kişinin servetini temsil eden konutlar, kişinin ödeme gücünün diğer bir emaresi olan tüketim, sanayii devrimi sonrası kurum kazançları üzerinden vergi konuları tespit edilerek vergilemeye gidilmiştir. Günümüzde robotlar, teknolojik işsizliğe ve kamu mali dengesinde bozulmalara yol açmasına karşılık robot 
teknolojisini kullanan şirketlerin karları devamlı olarak artmaktadır. Bu durum tarihsel olarak göz ardı edilen robotların vergilendirilmesi konusunun tartışılmasına yol açmıştır.

Robot vergisi getirilmesini savunan görüşlerin temelinde yatan argüman, vergilemede ayırma ilkesidir. Vergilemede ayırma ilkesi gereğince emek geliri sermaye geliri karşısında korunmalıdır. Bu amaçla insan emeği harcanarak elde edilen gelirler, sermaye kullanılarak elde edilen gelirlere göre daha düşük bir vergileme rejimine tabi tutulmalı, robot çalışanlar yerine insan emeğine yönelik teşvikler artırılmalıdır. Robotların vergilendirilmesi, sermaye sahipleri ve işçiler arasındaki ekonomik açığı genişleten otomasyonun yıkıcı etkilerini gidererek, en azından üretken girdiler arasında vergi tarafsızlı̆̆ını sağlayabilir. Böylece firmalar daha az vergi vermek için değil daha verimli olacakları zaman robotları kullanmaya karar verir, işçi çalıştırmanın artan ekonomik avantajları nedeniyle işsizliğin büyümesini yavaşlar ve ekonomik eşitsizlik azalır. Ancak çoğunlukla özel yatırımları ve ekonomik büyümeyi teşvik etme gerekçesi ile tarafsızlık ilkesi ihlal edilmektedir (Bottone, 2018, s.2).

Robot vergisi taraftarlarına göre aynı zamanda robot vergisi, vergi tabanını çevreye zarar maddelerin tüketimine vergi tabanını kaydırmayı (tax shift) ve böylece emek üzerinden alınan vergi oranlarını ve sosyal sigorta primlerini azaltmayı hedefleyen adil ve rasyonel bir vergi politikasına benzer faydalar ortaya çıkaracaktır (Durning ve diğ., 1998). Robot vergisi, vergi tabanının genişlemesine ve emek üzerinden alınan vergi oranlarının azalmasına yol açacaktır. Robot vergisinden elde edilecek gelir ile Rawlsian cehalet örtüsünün ardında, teknolojik işsizlikten mağdur olan kişilerin yeni beceriler kazanması için eğitim giderleri karşılanabilir, uzun süreli işsizlik maaşı bağlanabilir ve böylece toplumda emniyet supabı görevini yerine getirecek gerekli kamusal tedbirler alınabilir.

Robot vergisi getirilmesine karşı çıkan ve eleştiren kesimlerin öncelikli dayanak noktası, robot vergisinin inovasyonu engelleyeceği görüşüne dayanmaktadır. Özellikle kalkınmakta olan ülkelerde vergi nedeniyle robotların ya da robot kullanımı maliyetlerinin artması, şirketlerin teknolojik ilerlemeyi ve üretkenliği geliştirmeleri için varolan teşvikleri azaltacak, sonuçta verimliliği, rekabeti ve dolayısıyla büyüme ve istihdamı düşürecektir (Çetinkaya ve Akar, 2018, s. 52). Ayrıca yasal mevzuatta robot tanımının net olmaması ve bu nedenle vergi sisteminin daha karmaşık hale gelmesi halinde vergi uyum maliyetleri artacaktır (Kurt ve Bozoklu, 2019, s. 42). Otomasyonun teşvik edilmesi halinde artan verimlilik ve milli gelir artışı, insanlar gelecekte daha az mesai yaparak kendisine ve ailesi daha çok vakit ayırmasına imkan tanıyacaktır. Son olarak bir robot vergisinin, özellikle "bulutta" veya internette barındırılmasına ve uzaktan erişilmesine izin veren, fiziksel varlığı olmayan robotları kullanan şirketlerin, vergi olmayan avantajlı bölgelere gitmesine yol açacağı savunulmaktadır (Mazur, 2019, s. 300-301).

Robotların vergilendirmesine yönelik ilk ciddi girişim Avrupa Birliği'nde başlatıldı. Avrupa Parlamentosu, robotların "elektronik kişiler" olarak sınıflandırılmasını teklif eden robot yasası düzenlenmesini onaylamış ancak elektronik kişi sayılacak robotların sahipleri ya da işverenlerinden vergi alınması teklifi, yenilikleri engelleyici yönde kaygılarını vurgulayarak, 16 Şubat 2017 tarihinde reddedilmiştir (Reuters, 16.02.2007). Avrupa Parlamentosu'nun 
robotlardan vergi alınmasına karşı çıkan kararının ardından Bill Gates, bu tartışmayı, insan emeği ve makineler arasında adil bir rekabeti korumak, iş kaybı ve vergi gelirinin azaltılması sorunuyla başa çıkabilmek ve iş piyasasında otomasyonun hızını azaltmak amaçlarıyla robotların tıpkı yerini aldıkları işçiler gibi elde edilen gelir üzerinden vergilendirilmesi gerektiğini önererek yeniden gündeme taşımıştır. Gates, elde edilecek gelirin ise yaşlı bakımı, teknolojik işsizlere sosyal güvence katkısı ve yoksul öğrenciler için kullanılmasını önermiştir. 2017 Ağustos ayında ise Güney Kore hükümeti, otomasyon teknolojisine yapılan yatırımlar için mükelleflere uygulanabilecek vergi teşviklerini yüzde iki azaltmayı içeren reform tasarısını sundu (Mazur, 2019, s. 297). Otomasyon devrimi daha da hızlandıkça ve etkisi toplum genelinde hissedildiğinde, robot vergisi uygulamaya yönelik girişimlerin artacağı her türlü izahtan varestedir.

Robotlardan vergi almak için öncelikli olarak mevcut hukuksal altyapının değiştirilmesi ve robotların bir kişi olarak tanınmaları gerekmektedir. Ekim 2017 tarihinde Suudi Arabistan'da robot Sophia'ya vatandaşlık verilmiş ve Suudi vatandaşlarla aynı özlük haklarına sahip olmuştur (Griffin, 26.10. 2017). Ancak, vergi tarihinde insan olmayan oluşumlardan vergi alınması tartışmaları kapitalist toplumun gelişmesiyle başlamıştır. Birleşik Krallık'ta 1897 tarihli Salomon \& Co Ltd. davasında İngiliz Lordlar Meclisi, tüzel kişilik doktrinini oybirliğiyle onaylamış ve alacaklıların şirketin hissedarlarına dava açmasının önüne geçmiştir. Devletler; şirketleri, kooperatifleri, dernekleri ve vakıfları içerecek şekilde tüzel kişiliklerin listesini genişletmiştir (Oberson, 2017, s.251). Şirketlerin, kendisini oluşturan ortaklardan ayrı bir potansiyel vergi yükümlüsü olarak tanınması, tüzel kişiliğin ve özellikle sınırlı sorumluluğun verilmesi neticesinde elde edilmiştir.

Kurumlar vergisi örneği, üretme, geliştirme ve öğrenme kapasitelerine sahip olan ve ekonomik katma değer yaratan robotların da gerçek ve tüzel kişilere ek olarak "elektronik kişi” sıfatıyla yasal bir kişilik tanımlanarak bir vergi süjesi olarak kabul edilmesine hem ekonomik hem de anayasal bakış açısından sağlam bir gerekçe oluşturmaktadır. Böylece robotlar, şirketlerin bir demirbaşı olarak kabul edilmek yerine, sahiplerinden ve kullanıcılarından ayrı olarak elektronik kişi sıfatıyla vergi mükellefi olabilecek ve robotların yol açtığı ekonomik eşitsizliklerle mücadelede robotların vergilendirilmesi bir araç olarak kullanılabilecektir. Robotların kullanımından veya robotlardan çıkan bir ödeme kapasitesinin (örneğin elektronik sermaye şeklinde) tanınması durumunda robotlara atfedilebilecek ödeme yeteneği ortaya çıkacaktır (Oberson, 2017, s.253-254). Böylece, fütüristik bir öneri olarak, ödeme kapasitesine sahip olan robotların ekonomik aktivitelerinden kaynaklanan emsal gelirleri, bir işçinin çalışmasından elde edilen gelir gibi ele alınarak vergilendirmek mümkün olacaktır.

Robot vergisinin tasarımında, uluslararası vergilendirmedeki son gelişmelerin göz önüne alınması önem taşımaktadır (Abbott ve Bogenschneider, 2018; s.168; Bottone, 2018, s.2). Ülkeler, sermayeyi kendi yetki alanlarına çekmek için vergi rekabetine gireceklerdir. Çifte vergilendirmeye gidilmemesi, transfer fiyatlaması yapılmaması ve vergi rekabeti yaşanmaması için OECD veya BM düzeyinde koordineli bir çalışma yapılmalı, yeni vergi cennetlerinin oluşumuna izin verilmemelidir. 


\section{Sonuç}

İş, eğlence ve sağlık gibi hayatımızın her alanına kullanılmaya başlayan robotlar sosyal, ekonomik ve yasal düzen açısından birçok soruyu gündeme getirmektedir. Robot devriminin toplumda refahı artırması, insanların çalışma saatlerini azaltması, zor ve hatta tehlikeli faaliyetleri gerçekleştirmeleri ve ekonomik zenginliği artırması beklenmektedir. Bu kapsamda robot teknolojisinin gelişimi sonucunda yeni iş kolları ortaya çıkmış ve nitelikli işgücü istihdamında artış yaşanmıştır. Ancak üretim ve hizmet sektöründe robotların artan sayıda kullanımı, özellikle rutin işler ile vasıfsız işlerde çalışanların işlerini kaybetmelerine ya da daha düşük ücretler ile çalışmalarına, beyaz ve mavi yakalı çalışanlar arasında ücret farklarının giderek açılmasına, toplumda zenginliğin robotlara sahip olan ya da kullanan küçük bir sermayedar kesimde toplanmasına neden olduğu görülmektedir.

Teknolojik işsizleri yeni iş kolları için eğitmek ve işsizlik maaşları ile desteklenmesi ise kamusal harcamaların artmasına, gelirin işgücünden sermaye gelirine doğru kayması ise vergi rekabeti nedeniyle devletin vergi gelirlerinin azalması ve akabinde uzun vadeli mali dengesizliğin ortaya çıkması ile sonuçlanacaktır. Ticaret savaşlarının başladığı, elektronik ticaretin arttığı, üretimin robotlara ve diğer sermaye varlıklarına doğru evrim geçirdiği 21 . yüzyılda vergi sistemlerinin yeniden gözden geçirilmesi gerekmektedir.

Görülmektedir ki günümüzde mevcut vergi sistemleri, robotların değil esas olarak insan işçilerin vergilendirilmesi üzerine tasarlanmıştır. Yüksek karların elde edildiği ve yakın gelecekte vergi tabanını genişletmeye aday internet ve robot teknolojilerine mevcut vergi kanunlarında yeterince yer verilmemiş ya da muaf tutulmuşlardır. Vergilemede ayırma ilkesi gereğince emeğin robot kullanımı karşısında korunması gerekmektedir. Elektriği, yeterli ortam sıcaklığı, yağı ve suyu olduğu müddetçe kesintisiz çalışma kabiliyetine sahip, sendikası olmayan, ücret artışı istemeyen robotların insanlar ile aynı vergileme rejimine tabi tutulması, sermaye yerine emeğin daha çok vergilenmesi ile sonuçlanan vergi sistemin istenmeyen sonucudur.

İnovasyonu engelleyeceği düşüncesi ile özellikle gelişmiş ülkelerin robot vergisine karş1 çıkmalarına karşılık, 20. Yüzyılın başlarında uygulamaya konulan kurumlar vergisine benzer şekilde robotlara elektronik kişilik verilmesi ve kurumlar gibi ayrı vergileme rejimine tabi tutulması gerekmektedir. Devletlerin vergi sistemlerini robotlar ve insan işgücü arasında emekten yana ya da en azından tarafsız olacak şekilde dizayn etmelerinde robotların vergilendirilmesini hesaba katmadıkları takdirde başarısız kalacakları gerçeği her türlü izahtan varestedir. 


\section{Kaynakça}

Abbott, R. ve Bogenschneider, B. (2018). Should Robots Pay Taxes? Tax Policy in the Age of Automation. Harvard Law \& Policy Review, 12, 145-175.

Allen, R. C. (2017). The Industrial Revolution: A Very Short Introduction. USA: Oxford University.

Asimov, I. (2013). I, Robot. USA: Harper Collins.

Bootle, R. (2019). The AI Economy: Work, Wealth and Welfare in the Age of the Robot. Nicholas Brealey Publishing.

Bottone, G. (2018). A Tax on Robots? Some food for thought, DF Working Papers, No:3.

Cevizci, A. (2001). İlkçă̆ Felsefe Tarihi. 3. Baskı, Bursa: Asa.

Chace, C. (2016). The Economic Singularity: Artificial Intelligence and the Death of Capitalism. London: Three Cs.

Çetinkaya, G. ve Akar, S. (2018). Robotlar Vergi Vermeli mi? Türkiye Açısından Değerlendirme. İçinde: Current Debates in Public Finance \& Public Administration, Ed:Akar. S, ve Şenbel Eser, D. IJOPEC Publication Limited, 45-56.

Çomaklı, Ş.E. ve Turan, D. (2016). Kamu Harcama Hukuku, No:12, Ankara: Polis Akademisi.

Delvaux, M. (27.1.2017). Report with Recommendations to the Commission on CivilLaw Rules on Robotics, Committee on Legal Affairs, url'si. (2015/2103(INL), https://www.europarl.europa.eu/doceo/document/A-8-2017-0005_EN.html

Dunlop, T. (12.03. 2017). What Is a Robot Exactly-and How Do We Make It Pay Tax?. Guardian. url'si. https://www.theguardian.com/sustainable-business/2017/mar/13/whatis-a-robot-exactly-and-how-do-we-make-it-pay-tax

Durning. A.T., Bauman, Y. ve Gussett, R., Northwest Environment Watch. (1998). Tax Shift: How to Help the Economy, Improve the Environment, and Get the Tax Man Off Our Backs. Sightline Inst.

Ela, M. (2019). Teknolojik İşsizlik Problemine Mali Çözüm: Robot Vergisi ve Türkiye'deki Potansiyeli. Muhasebe ve Vergi Uygulamaları Dergisi. 12 (3), 885-906.

Griffin, A. (26.10. 2017). Saudi Arabia Grants Citizenship To A Robot For The First Time Ever, Independent, url'si. https:/www.independent.co.uk/life-style/gadgets-and-tech/news/ saudi-arabia-robot-sophia-citizenship-android-riyadh-citizen-passport-future-a80216 01.html

Guerreiroy, J., Rebeloz, S. ve Teles, P. (February 2018). Should Robots Be Taxed?, Ademu Working Paper Series, WP 2017/085. url'si. https://pdfs.semanticscholar.org/f409/ 1d3b02ed9406448c69df76983bbf55edd190.pdf

Johannessen, J.A. (2019). The Workplace of the Future: The Fourth Industrial Revolution, the Precariat and the Death of Hierarchies, Routledge. 
Kurt, D. ve Bozoklu, Ü. (2019). Robot Ekonomisinin Yükselişi. Sosyal Bilimler Metinleri, 2019/0, 125-147.

Manyika, J., Lund, S., Chui, M., Bughin, J., Woetzel, J., Batra, P., Ko, R., Sanghvi, S. (December 2017). Jobs Lost, Jobs Gained: Workforce Transitions In a Time of Automation, McKinsey Global Institute. url'si. https://www.mckinsey.com/ /media/McKinsey/Featured\%20 Insights/Future\%20of\%20Organizations/What\%20the\%20future\%20of\%20work\%20will \%20mean\%20for\%20jobs\%20skills\%20and\%20wages/MGI-Jobs-Lost-Jobs-Gained-Rep ort-December-6-2017.ashx

Marcovitz, H. (2013). The Industrial Revolution. ReferencePoint Press.

Marwala, T. (2018). On Robot Revolution and Taxation, Cornell University. url'si. https://arxiv.org/ftp/arxiv/papers/1808/1808.01666.pdf

Marx, K. (2011). Capital. 1.Cilt, Kapitalis Üretimin Eleştirel Bir Tahlili, Çev: Alaattin Bilgi, Ankara: Sol.

Mazur, O. (2019). Taxing the Robots. Pepperdine Law Review. 46(277), 277-330.

Oberson, X. (05.2017). Taxing Robots? From the Emergence of an Electronic Ability to Pay to a Tax on Robots or the Use of Robots. World Tax Journal, 247-261.

Okan Gökten, P. (2018). Karanlıkta Üretim: Yeni Çağda Maliyetin Kapsamı. Muhasebe Bilim Dünyası Dergisi, 20(4), 880-897.

Popkova, E. G., Ragulina, Y. V., Bogoviz, A. V. (2019). Industry 4.0: Industrial Revolution of the 21st Century. Springer International Publishing.

Rathi, A. ve Hawking S. (09.10.2015). Robots aren't just taking our jobs, they're making society more unequal. Quartz, url'si. http://qz.com/520907/stephen-hawking-robotsarent-justtaking-our-jobs-theyre-making-society-more-unequal

Reuters Staff, (16.02.2007). European Parliament Calls for Robot Law, Rejects Robot Tax. Reuters. url'si. http://ca.reuters.com/article/technologyNews/idCAKBN15V2KM

Turner, J. (2019). Robot Rules-Regulating Artificial Intelligence-, Palgrave Macmillan, London. Vonnegut, K. (1952). Piano Player. USA: Charles Scribner's Sons. 